\title{
Tystnaden och Beckett
}

\section{av Vasilis Papageorgiou}

Först några ord om författaren Samuel Beckett. Han föddes 1906 i Dublin. Han studerade engelska, franska och italienska på Trinity College. Han arbetade som lärare på École Normale Supérieure i Paris och senare på Trinity College i Dublin. Han debuterade 1930 med diktsamlingen Whoroscope. 1937 flyttade han till Paris, denna gång för att stanna. Här blev han god vän med James Joyce. Strax efter andra världskriget började han skriva på franska. Han skrev sina bästa verk på detta språk. Han tilldelades Nobelpriset i litteratur 1968. Han avled 1989. Av hans prosaverk kan nämnas romantrilogin Molloy, Malone dör, och Den onämnbare. Av hans mest kända dramer kan man nämna I väntan på Godot och Slutspel. Alla dessa texter skrev han på franska inom en intensiv period av nio eller tio år.

Titeln på denna artikel är "Tystnaden och Beckett" och inte "Beckett och Tystnaden", vilket skulle vara ett mer naturligt sätt att uttrycka Becketts förhållande till tystanden. För att det är detta som artikeln kommer att handla om och inte om tystnadens förhållande till Beckett. Ändå väljer jag uttrycket "Tystnaden och Beckett”. Jag hoppas att jag ska kunna förklara varför.

I dag känns det överflödigt, som en pleonasm, att säga att Beckett har odlat tystnaden och dess fysiska eller metafysiska implikationer, dess estetiska och filosofiska dimensioner. Namnet Beckett har blivit synonymt med termer som inaktivitet, apati, hopplöshet, förlamning, meningslöshet och, ja, tystnad. Hänvisningar till tystnaden finns i nästan alla hans texter. Hade han kunnat, vore det överhuvudtaget möjligt, hade han skrivit en text som enbart består av tystnad. Han lyckades nästan när han 1969 skrev pjäsen Breath. Dramats mycket korta längd, det är bara trettiofem sekunder långt, talar redan om författarens pakt med tystnaden som blir påtaglig av att det enda som hörs på den på människor tomma scenen är två svaga skrik, en inandning och en utandning.

Man kan också, om man så vill, utforska den existentiella roll som tystnaden har spelat för Beckett som författande människa. Hans beslut att till slut skriva sina verk direkt på franska kan ses i ljuset av hans egen uppfattning om tystnaden. Han har förklarat sitt val på olika sätt, men alla kan kopplas till hans sätt att inspireras av tystnaden. Han har en gång berättat att det att skriva på franska var för honom ett sätt att undvika att bry sig om att utveckla en egen litterär stil. Den litterära stilen liknade han vid en slips som man knyter runt halsen för att dölja strupcancern. En annan gång har han berättat att han övergav sitt modersmål, engelskan, för att det var för konkret, medan franskan var byggd på ett mycket mer komplicerat och retoriskt sätt. Man kunde använda sig av franskan på ett sådant sätt att man inte behövde ha någon direkt kontakt med den erfarenhet eller bild man skrev om. Man kunde alltså, när man skrev på franska, lämna världen bakom sig och gömma sig i språkets abstraktioner, i den tystnad dessa genererar. 
Med den första förklaringen menar Beckett möjligen att om man skriver på ett språk som inte är ens modersmål, ett språk som man har lärt sig på ett mer eller mindre tekniskt sätt, då skapar stilen sig själv, man behöver inte slåss för att distansera och differentiera sig från de författare man beundrar och har låtit sig påverkas av. Det skulle ha varit svårare för Beckett att finna sin egen stil på engelska än på franska. Antingen man vill det eller inte uppstår det omedelbart en litterär stil på grund av det särskilda, begränsade förhållande som en författare kan ha till ett språk som man tillägnat sig. Och stilen behöver man för att dölja strupcancern, för att lättare hantera den invecklade tystnad som strupcancern innebär.

Den andra förklaringen, det att det franska språket är retoriskt och abstrakt, och att just detta hjälpte Beckett att undvika den direkta kontakten med den fysiska verkligheten, också denna förklaring kan vi föra samman med hans väl övervägda förhållande till tystnaden. När man vill skriva inifrån tystnaden, när man använder tystnaden som förutsättning för det som man ska säga eller skriva, då verkar det vara oundvikligt att man distanserar sig från det medium som man talar eller skriver genom och från den omedelbara verklighet som omger en och som alltid finns med, följer med och helt objuden dyker upp varje gång man kommer i kontakt med världen. Att skriva på engelska betydde troligen för Beckett att han måste ta hänsyn till den engelska litterära stilistiken samt till de empiriska erfarenheter och de metafysiska anspråk som användandet av ens eget språk förutsätter eller medför. Att skriva på engelska betydde alltså att engelskan talade till honom, genom honom, innan han talade till eller genom det, att engelskan använde sig av honom, innan han använde sig av den. Och detta intresserade honom uppenbarligen inte. Han behövde tystnaden. Han ville istället skriva på ett främmande språk, ty då börjar man lättare från tystnaden och letar efter ord som kommer ut ur tystnaden. Ord som bär tystnaden inom sig. Efter att ha gjort så, skrivit i ett annat språk, var det återigen meningsfullt att återvända till sitt eget. Beckett översatte själv sina franska texter till engelska. Då hade han redan närmat sig sin egen tystnad, hade redan gjort den påtaglig.

Jag har alltså berört Becketts säregna förhållande till tystnaden. Att den är en förutsättning för hans författarskap, att han skriver inifrån tystnaden, att orden i hans texter bär tystnaden inom sig. Det är nu som jag ska försöka förklara vad jag menar med titeln på denna artikel, att den heter "Tystnaden och Beckett" och inte "Beckett och Tystanden". Det är Beckett själv som har lagt fram de hårda villkor som gäller för den som vill vara en banbrytande konstnär. Det var 1949, mitt i arbetet med trilogins sista roman, som Beckett, i en text som heter Tre dialoger med Georges Duthuit, presenterade sina tankar om vad det innebär att vara en riktigt banbrytande konstnär. Han talar där om olika målare, men det är själva skapandet han egentligen vill närma sig, det att avbilda konkreta eller abstrakta föremål och uppfattningar. I dessa korta dialoger läser vi att det för Beckett är omöjligt att avbilda något. Att vara konstnär betyder att man kommer att misslyckas med det man egentligen vill åstadkomma. Man kan alltid försöka uttrycka omöjligheten att uttrycka, men man kan aldrig uttrycka det man verkligen vill uttrycka. Mellan världen, konstnären och konstverket finns ett avstånd, ett tomrum, en tystnad som gör att vi närmar oss varandra med hjälp av olika 
sorters språk. Vi kan aldrig komma i direkt kontakt med andra människor, med världen, med oss själva, med vår uppfattning om oss själva och våra produkter. Det att konstnären måste skapa med hjälp av ett givet språk tar ifrån henne eller honom möjligheten att säga någonting eget eller nytt. Varje språk uttrycker bara en språklig avvikelse, skriver han i Molloy. Beckett talar med beundran om målaren Bram van Velde, för att han menade att målaren lyckades med att misslyckas, han, målaren, var medveten om att "det inte finns någonting att måla och ingenting att måla med”. Med dessa ord om måleriet har han, som bekant, beskrivit både sitt eget skrivande och sina hjältars tänkande.

Men redan 1937, i ett brev, skrev Beckett så här: "Mer och mer tycks mig mitt språk vara en slöja som man måste riva sönder för att nå fram till de bakomliggande tingen (eller det bakomliggande Intet)." Och han tillade om språket: "Att borra hål efter hål i det tills det bakomkurande, oavsett om det är någonting eller ingenting, börjar sippra igenom - jag kan inte föreställa mig ett högre mål för en nutida författare."

Drygt tio år senare visste han att det inte finns någonting bakom språkets slöja. Att denna slöja döljer en grundläggande tystnad, att till och med slöjan är en allegori för denna tystnad, den står för, den vittnar om och skapar denna tystnad. Tystnaden kommer först. Den följer inte talet, den skapas inte för att orden har bestämt sig för att ta en paus. Det är inte orden som bestämmer över tystnaden, det är tystnaden som bestämmer över orden. Det är inte fråga om en tystnad som talar genom att vara tyst eller suggestiv, som utgör en bro mellan ord och avsikter. Det är fråga om en tystnad som talar om omöjligheten att säga något som är sant, en tystnad som aldrig säger något även när den talar.

Det är denna andra tystnad som hans texter försöker göra påtaglig. Han visste att allt han skrev bara uttrycker en avvikelse från det som han egentligen ville uttrycka. Och det är hans omöjliga tystnad som orsakar denna avvikelse. För att kunna bevara denna omöjliga tystnad måste han skriva sina avvikelser. Att helt sluta skriva är ovidkommande för Beckett och det är omöjligt att skapa den totala tystnaden, just därför att det är omöjligt att skapa det man egentligen vill. Det enda sättet att låta denna omöjliga tystnad bli påtaglig är att låta den uttryckas av avvikande texter och personer: ämnen och litterära stilar som radikalt skiljer sig från den övriga modernismens, hjältar som saknar spår av eller vilja till heroism, vilka tvärtom befinner sig i livets sociala, fysiska och andliga utkanter, där tystnaden redan har öppnat sin avgrund. 